\title{
Thevetiaflavone from Wikstroemia indica ameliorates PC12 cells injury induced by OGD/R via improving ROS-mediated mitochondrial dysfunction
}

\author{
HUANKAI YAO ${ }^{1}$, ZHENHAI YUAN ${ }^{2}$, GUANGMING WEI ${ }^{3}, \mathrm{CHUN} \mathrm{CHEN}^{1}$, JINGYU DUAN ${ }^{1}$, \\ YAN LI ${ }^{1}$, YUNRU WANG ${ }^{3},{\text { CHUNPING } \text { ZHANG }^{1} \text { and YUANHUA LIU }}^{3}$ \\ ${ }^{1}$ School of Pharmacy and Jiangsu Key Laboratory of New Drug Research and Clinical Pharmacy, \\ Xuzhou Medical University, Xuzhou, Jiangsu 221004; ${ }^{2}$ Shandong Academy of Pharmaceutical Sciences, Jinan, \\ Shandong 250101; ${ }^{3}$ Department of Pharmacy, Taian City Central Hospital, Taian, Shandong 271000, P.R. China
}

Received May 12, 2017; Accepted September 27, 2017

DOI: $10.3892 / \mathrm{mmr} .2017 .7712$

\begin{abstract}
Cerebral ischemia and following reperfusion affects many people worldwide. To discover efficient therapeutic approaches, numerous natural products have been investigated. The current study investigated the protective effects of thevetiaflavone, a natural flavonoid obtained from Wikstroemia indica, and the associated mechanisms using PC12 cells induced by oxygen and glucose deprivation. As a result, thevetiaflavone improves cell viability and suppresses the leakage of lactate dehydrogenase from the cytoplasm. Further investigation of the mechanisms demonstrated that thevetiaflavone decreases overproduction of ROS and ameliorates ROS-mediated mitochondrial dysfunction, including collapse of mitochondrial membrane potential and mitochondrial permeability transition pore opening. Thevetiaflavone reduces the intracellular $\mathrm{Ca}^{2+}$ level, which is closely associated with mitochondrial function and interplays with ROS. Furthermore, thevetiaflavone inhibits apoptosis in $\mathrm{PC} 12$ cells through upregulating the expression of $\mathrm{Bcl}-2$ and downregulating that of Bax and caspase- 3 in addition to increasing the activity of caspase-3. These results further indicate the protective effects of thevetiaflavone in vivo and its application in the clinic.
\end{abstract}

Correspondence to: Dr Chunping Zhang, School of Pharmacy and Jiangsu Key Laboratory of New Drug Research and Clinical Pharmacy, Xuzhou Medical University, 209 Tongshan Road, Xuzhou, Jiangsu 221004, P.R. China

E-mail: chunpingzhang520@163.com

Dr Yuanhua Liu, Department of Pharmacy, Taian City Central Hospital, 29 Longtan Road, Taian, Shandong 271000, P.R. China E-mail: yhliuta@126.com

Key words: thevetiaflavone, PC12 cells, oxygen and glucose deprivation, mitochondrial dysfunction, apoptosis

\section{Introduction}

Cerebral stroke is a major cause of mortality and morbidity in adults around the world, and the global occurrence of stroke has markedly increased (1). Ischemic stroke accounts for about $87 \%$ of all stroke (2), and there are few effective therapeutic approaches for ischemic stroke (3). Though the pathology of ischemic stroke remains to be fully elucidated, several mechanisms including excitoxicity, oxidative stress, inflammation and apoptosis are involved (4). The interruption of blood flow in the brain will lead to the neuronal injury due to the oxygen and glucose deprivation (OGD), and timely reperfusion will exacerbate the damage due to the accumulation of reactive oxygen species (ROS) in mitochondria $(5,6)$. This accumulation results in destruction of the mitochondria because the brain is susceptible to ROS (4). In addition, neurons in the penumbra will undergo mitochondrion-mediated apoptosis (5). In the discovery of novel therapeutic options for ischemic stroke, natural compounds serve a pivotal role, for example resveratrol (7), mangiferin (8) and kaempferide-7-O-(4"-O-acetylrha mnosyl)-3-O-rutinoside (9).

Wikstroemia indica is a medicinal plant belonging to the family of Thymelaeaceae and is distributed throughout northern China. In traditional Chinese medicine, it has been used for the treatment of arthritis, tuberculosis, syphilis and pertussis (10). Phytochemical investigations on this plant have identified that the major chemical constituents include flavonoids (11-13), lignans $(14,15)$ and coumarins $(16,17)$. The current study aimed to investigate bioactive phytochemicals for the prevention of ischemic stroke by determining the chemical constituents from the roots of Wikstroemia indica and examining their neuroprotective effects. In the current study, it was reported that thevetiaflavone isolated from Wikstroemia indica demonstrated protective effects on PC12 cells induced by oxygen and glucose deprivation/reoxygenation (OGD/R) and relevant mechanisms.

\section{Materials and methods}

Chemicals and reagents. Thiazolyl blue tetrazolium bromide (MTT), and dimethyl sulfoxide (DMSO) were purchased from 
Shanghai Aladin Biochemal Technology Co., Ltd. (Shanghai, China). Dulbecco's modified Eagle's medium (DMEM) was obtained from Invitrogen (Thermo Fisher Scientific, Inc., Waltham, MA, USA). ROS, lactate dehydrogenase (LDH) and bicinchoninic acid (BCA) assay kits were obtained from Nanjing Jiancheng Bioengineering Institute (Nanjing, China). MitoProbe transition pore assay kit was from Thermo Fisher Scientific, Inc.. Rhodamine-123, Fluo-3 AM and caspase-3 assay kits in addition to cleaved caspase-3, Bcl-2, Bax and $\beta$-actin antibodies were purchased from Beyotime Institute of Biotechnology (Nantong, China).

Isolation of thevetiaflavone. The roots of Wikstroemia indica $(5.0 \mathrm{~kg})$ were collected in July 2011 in Luofu Mountain (China), and were identified by one of the authors, Dr Chunping Zhang. The voucher specimen (Y20110701) was deposited in Xuzhou Medical University.

The air dried roots of Wikstroemia indica were ground and extracted with petroleum ether and acetone successively. The acetone extract ( $240 \mathrm{~g}$ ) was repeatedly subjected to common column on silica gel with gradient dichloromethane/methnol (from 100:0 to 70:30) and yielded a yellowish powder $(18.0 \mathrm{mg})$. The structure of this compound was determined as thevetiaflavone by analysis of ${ }^{1} \mathrm{H}$ and ${ }^{13} \mathrm{C}$ NMR spectra in addition to comparison with the data reported (18).

Cell culture and treatment. Rat adrenal pheochromocytoma cells (PC12 cells), the neuron-like cells, were obtained from Cell Bank of Shanghai Institute of Biological Sciences, Chinese Academy of Sciences (Shanghai, China). The cells were cultured in DMEM containing $10 \%$ fetal bovine serum, $1 \%$ penicillin and streptomycin at $37^{\circ} \mathrm{C}$ in a humid atmosphere with $5 \% \mathrm{CO}_{2}$ and $95 \%$ air. Then the OGD/R was performed as described previously (19). Briefly, subsequent to the normal medium being replaced by glucose-free DMEM, the cells were cultured under a $95 \% \mathrm{~N}_{2}$ and $5 \% \mathrm{CO}_{2}$ atmosphere at $37^{\circ} \mathrm{C}$ in the presence or absence of certain concentrations of thevetiaflavone $(0.1,1$ and $10 \mu \mathrm{M})$ for $4 \mathrm{~h}$. Subsequently, the cells were cultured again under normal conditions $\left(5 \% \mathrm{CO}_{2}\right.$ and $95 \%$ air) for $24 \mathrm{~h}$ with or without thevetiaflavone. The cells in the control group were cultured at a normal atmosphere.

Cell viability assay. The PC12 cell viability was evaluated through the MTT assay. The cells were cultivated in 96-well microplates at $1 \times 10^{5}$ per well. After treatment as above, MTT $(0.5 \mathrm{mg} / \mathrm{ml})$ was added into each well and the mixture was incubated for $4 \mathrm{~h}$ at $37^{\circ} \mathrm{C}$. Subsequently, the medium was removed and the formazan was dissolved in DMSO. After $10 \mathrm{~min}$, the optical density (OD) was recorded on a microplate reader at $550 \mathrm{~nm}$. The cell viability was expressed as the relative percentage of OD values compared with the control group.

Extracellular LDH activity. For the leakage of intracellular LDH is associated with the cell survival, the extracellular LDH activity in cells medium was measured by the LDH assay kit. Following treatment, the supernatant $(20 \mu \mathrm{l})$ in each well was collected and tested following the manufacturer's instructions. Thereafter the OD values were recorded on a microplate reader at $450 \mathrm{~nm}$. The activity extracellular $\mathrm{LDH}$ was derived from the OD values as U/1.
Level of intracellular ROS. For the excessive production of ROS induced by OGD/R will promote the injury, the level of intracellular ROS was assayed by an assay kit following the manufacturer's instructions. Following treatment, the cells were rinsed with PBS and $10 \mu \mathrm{M}$ DCFH-DA solution was added. Then the incubation was implemented for $30 \mathrm{~min}$ at $37^{\circ} \mathrm{C}$. The cells were washed with PBS and then the fluorescence intensity of hydrolyzed DCFH-DA was determined by a fluorescence spectrophotometer at excitation wavelength of $485 \mathrm{~nm}$ and emission wavelength of $520 \mathrm{~nm}$.

Intracellular $\mathrm{Ca}^{2+}$ level. Increasing ROS will cause the overload of intracellular $\mathrm{Ca}^{2+}$ through activating signaling transduction cascades. High levels of $\mathrm{Ca}^{2+}$ will result in the overproduction of $\operatorname{ROS}(20)$, and in order to determine the intracellular $\mathrm{Ca}^{2+}$ level, the fluorescence probe Fluo-3 AM has been used previously (7). The treated PC12 cells were washed with PBS three times, and incubated with Fluo-3 AM at $37^{\circ} \mathrm{C}$ for $30 \mathrm{~min}$ in the dark. Then the cells were washed with PBS to remove excessive extracellular dye. The fluorescence intensity was immediately detected on a fluorescence spectrophotometer at $488 \mathrm{~nm}$ for excitation and $525 \mathrm{~nm}$ for emission.

Mitochondrial membrane potential (MMP). MMP of PC12 cells was quantified by a fluorescence probe rhodamine-123, which accumulates in mitochondria of living cells. However if there is a collapse of MMP, rhodamine-123 will release from mitochondria due to the membrane depolarization. The treated PC12 cells were incubated with $2 \mu \mathrm{M}$ rhodamine-123 for $15 \mathrm{~min}$. Subsequently, the fluorescence intensity was recorded on a fluorescence spectrophotometer and the excitation wavelength in addition, emission wavelength was set at $488 \mathrm{~nm}$ and $525 \mathrm{~nm}$ respectively. The MMP level was expressed as the ratio compared with the control group.

Mitochondrial permeability transition pore (mPTP) opening. To further investigate the function of mitochondria in $\mathrm{PC} 12$ cells induced by OGD/R, mPTP opening was detected by the calcein-AM loading $/ \mathrm{Co}^{2+}$ quenching technique through a MitoProbe transition pore assay kit following the manufacturer's instructions. The non-fluorescent calcein-AM can freely pass through the cellular membrane to be hydrolyzed by intracellular esterases as fluorescent calcein, which is captured inside cells. The loading of $\mathrm{Co}^{2+}$ can quench the intracellular fluorescence of calcein except that in mitochondria, for $\mathrm{Co}^{2+}$ cannot enter mitochondria. Therefore, when mPTP opens, the fluorescence of calcein in mitochondria will be quenched by $\mathrm{Co}^{2+}(21)$. The PC12 cells were pre-treated as above, and washed with PBS for three times. Then the cells were suspended in Hanks' balanced salt solution supplemented with $2 \mathrm{mM} \mathrm{Ca}^{2+}$ (HBSS/Ca ${ }^{2+}$ ), and incubated with $2 \mu \mathrm{M}$ Calcein-AM and $1 \mathrm{mM} \mathrm{CoCl}_{2}$ at $37^{\circ} \mathrm{C}$ for $30 \mathrm{~min}$ in dark. Subsequently to washing with HBSS to remove the excessive reagents, the cells were resuspended in $\mathrm{HBSS} / \mathrm{Ca}^{2+}$. The fluorescence intensity of calcein was directly detected on a fluorescence spectrophotometer at $494 \mathrm{~nm}$ for excitation and $517 \mathrm{~nm}$ for emission, and at least $1 \times 10^{4}$ events per sample were acquired.

Intracellular ATP level. The intercellular ATP was determined by a firefly luciferase method according to the manufacturer's 
protocol of the assay kit. ATP is consumed quantitatively when the luciferin emits fluorescence under the catalysis of firefly luciferase. The treated PC12 cells were lysed on ice with $200 \mu 1$ lysis solution from the assay kit. Then the lysate was centrifuged at $12,000 \mathrm{xg}$ for $4 \mathrm{~min}$ at $4^{\circ} \mathrm{C}$. Thereafter supernatant $(100 \mu \mathrm{l})$ was aspirated for the quantification and $100 \mu \mathrm{l}$ ATP monitoring reagent was added. The luminescence was detected on the fluorescence spectrophotometer. The level of intracellular ATP was calculated from the standard curve and expressed as the percentage associated with the control group.

Caspase- 3 activity. The activity of Caspase-3 in PC12 cells was tested by a colorimetric assay kit according to the manufacturer's instruction. Following treatment, the cells were washed with PBS. Then the cells were lysed on ice and centrifuged at $16,000 \mathrm{x} \mathrm{g}$ and $4^{\circ} \mathrm{C}$ for $10 \mathrm{~min}$. The supernatant was sucked and incubated with substrate (Ac-DEVD-pNA) at $37^{\circ} \mathrm{C}$ for $2 \mathrm{~h}$. The OD values were recorded on a microplate reader at $405 \mathrm{~nm}$. The relative activity of caspase- 3 was expressed as the OD values of the product $p$ NA produced by caspase- 3 .

Western blot analysis. The treated PC12 cells were subjected to western blot analysis for the expression of caspase-3, Bcl-2, and Bax. The cells were lysed on ice for $30 \mathrm{~min}$ with lysis solution containing $20 \mathrm{mM}$ Tris- $\mathrm{HCl}$ (pH 7.4), $150 \mathrm{mM} \mathrm{NaCl}$, $1 \%$ Triton and $1 \mathrm{mM}$ phenylmethylsulfonyl fluoride. Then the lysate was centrifuged at $10,000 \mathrm{x}$ g for $15 \mathrm{~min}$ at $4^{\circ} \mathrm{C}$, and the supernatant was collected as the total protein for the following analysis. The total protein was determined by a BCA assay kit, and subsequently separated by $15 \%$ sodium dodecyl sulfate polyacrylamide gel electrophoresis. Then the samples were transferred to a polyvinylidene fluoride membranes. The membranes were blocked with nonfat milk at room temperature, and then incubated overnight with primary antibodies of cleaved caspase-3 (cat no. AC033; 1:1,000), Bcl-2 (cat no. AB112; 1:1,000), Bax (cat no. AB026; 1:1,000) and $\beta$-actin (cat no. AF0003; $1: 1,000$ ) at $4^{\circ} \mathrm{C}$. After washing three times with buffer solution including $0.1 \%$ Tween-20, the membranes were incubated with the corresponding secondary antibody (cat no. A1092; 1:1,000) conjugated with horseradish peroxidase in blocking solution at room temperature for $1 \mathrm{~h}$ and detected by enzyme-linked chemiluminescence substrate. $\beta$-actin was used as the internal control.

Statistical analysis. All data were expressed as the mean \pm standard deviation and analyzed by GraphPad Prism version 5.0 (GraphPad Software, Inc., La Jolla, CA, USA). Data among different groups were analyzed by one way analysis of variance followed by Dunnett test for multiple comparisons and Student's t-test for single comparisons. $\mathrm{P}<0.05$ was considered to indicate a statistically significant difference.

\section{Results}

Phytochemical investigation. The structure of thevetiaflavone can be elucidated by analysis of ${ }^{1} \mathrm{H}$ and ${ }^{13} \mathrm{C}$ NMR spectra. In ${ }^{1} \mathrm{H}$ NMR spectra, $\delta_{\mathrm{H}} 6.38(1 \mathrm{H}, \mathrm{d}, J=2.2 \mathrm{~Hz})$ and $6.78(1 \mathrm{H}, \mathrm{d}$, $J=2.2 \mathrm{~Hz}$ ) are proton signals in an AX system, which indicate there is a benzene with two hydrogen atoms in meta position. $\delta_{\mathrm{H}} 7.96(2 \mathrm{H}, \mathrm{d}, J=8.8 \mathrm{~Hz})$ and $6.93(2 \mathrm{H}, \mathrm{d}, J=8.8 \mathrm{~Hz})$ are proton signals in an $\mathrm{A}_{2} \mathrm{X}_{2}$ system, which belong to the benzene ring with substitution in para position. In addition, proton signal of methoxyl hydrogen atoms can be detected at $\delta_{\mathrm{H}} 3.87(3 \mathrm{H}, \mathrm{s})$. In ${ }^{13} \mathrm{C}$ NMR spectrum, there are 15 carbon signals together with the carbon signal of methoxyl group at $\delta_{C} 56.2$. These data are in accordance with our former report (18), the structure of this compound can be identified as thevetiaflavone (Fig. 1). The ${ }^{1} \mathrm{H}$ and ${ }^{13} \mathrm{C}$ NMR data were assigned as following: ${ }^{1} \mathrm{H}$ NMR

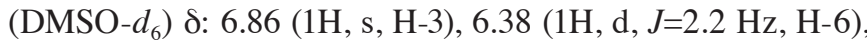
$6.78(1 \mathrm{H}, \mathrm{d}, J=2.2 \mathrm{~Hz}, \mathrm{H}-8), 7.96\left(2 \mathrm{H}, \mathrm{d}, J=8.8 \mathrm{~Hz}, \mathrm{H}-2^{\prime}, 6^{\prime}\right)$, $6.93\left(2 \mathrm{H}, \mathrm{d}, \mathrm{J}=8.8 \mathrm{~Hz}, \mathrm{H}-3^{\prime}, 5^{\prime}\right), 3.87\left(3 \mathrm{H}, \mathrm{s},-\mathrm{OCH}_{3}\right) ;{ }^{13} \mathrm{C} \mathrm{NMR}$ $\left(\mathrm{DMSO}-d_{6}\right) \delta: 164.2$ (C-2), 103.2 (C-3), 182.1 (C-4), 157.4 (C-5), 98.1 (C-6), 165.3 (C-7), 92.8 (C-8), 161.3 (C-9), 104.8 (C-10), $121.2\left(\mathrm{C}^{-1}\right), 128.7$ (C-2', 6'), 114.4 (C-3', 5'), 161.5 (C-4'), $56.2\left(-\mathrm{OCH}_{3}\right)$.

Effect of thevetiaflavone on the viability of PC12 cells induced by $O G D / R$. As presented in Fig. 2, treatment by $\mathrm{OGD} / \mathrm{R}$ could result in the poor viability of PC12 cells $(52.93 \pm 3.87 \%$, $\mathrm{P}<0.001)$ compared with the control group. When pre-treated with thevetiaflavone, the survival of PC12 cells was apparently improved in a dosage-dependent manner (59.37 \pm 5.70 , $65.72 \pm 6.23$ and $77.89 \pm 7.48 \%$ ), which indicated the protective effect of thevetiaflavone on PC12 cells injured by OGD/R.

Effect of thevetiaflavone on the release of $L D H$. To evaluate the protective effects of thevetiaflavone, the extracellular LDH activity released was evaluated. Consequently, OGD/R can significantly increase the activity of extracellular $\mathrm{LDH}$ as $84.27 \pm 6.29 \mathrm{U} / 1$ compared with the control group (42.06 $\pm 4.37 \mathrm{U} / 1, \mathrm{P}<0.001$ vs. control group). In contrast, in the presence of thevetiaflavone, the activity will be reduced as $77.42 \pm 2.55,67.59 \pm 5.29$ and $62.20 \pm 5.03 \mathrm{U} / 1$, respectively (Fig. 3). These results further validate thevetiaflavone can improve the viability of PC12 cells injured by OGD/R.

Effect of thevetiaflavone on ROS production in PC12 cells induced by $O G D / R$. The production of intracellular ROS was detected. As a result, OGD/R can lead to the overproduction of intracellular ROS $(325.49 \pm 15.33, \mathrm{P}<0.001$ vs. the control group) and thevetiaflavone can clearly suppress this overproduction $(289.15 \pm 21.72,212.46 \pm 28.74$ and $190.44 \pm 24.47)$ (Fig. 4).

Effect of thevetiaflavone on intracellular $\mathrm{Ca}^{2+}$ in PC12 cells induced by $O G D / R$. As presented in Fig. 5, the intracellular $\mathrm{Ca}^{2+}$ level was sharply elevated by OGD/R (780.01 \pm 34.28 , $\mathrm{P}<0.001$ vs. control group). And with different concentrations of thevetiaflavone, the levels of intracellular $\mathrm{Ca}^{2+}$ were significantly reduced as $712.01 \pm 65.03,614.23 \pm 410.14$ and $542.14 \pm 60.14$.

Effect of thevetiaflavone on MMP and MPTP in PC12 cells induced by $O G D / R$. Herein, we have found OGD/R can damage the function of mitochondria in PC12 cells including decreasing MMP (36.22 $\pm 7.15 \%, \mathrm{P}<0.001$ vs. control group) and increasing the mPTP opening $(48.44 \pm 4.67 \%, \mathrm{P}<0.001$ vs. control group). In the presence of thevetiaflavone, the collapse of MMP was attenuated $(44.50 \pm 4.88 \%, 58.42 \pm 6.46$ and $78.89 \pm 6.02 \%$; Fig. 6), and blocking of the mPTP opening 
<smiles>COc1cc(O)cc2oc(-c3ccc(O)cc3)cc(=O)c12</smiles>

Figure 1. Chemical structure of thevetiaflavone.

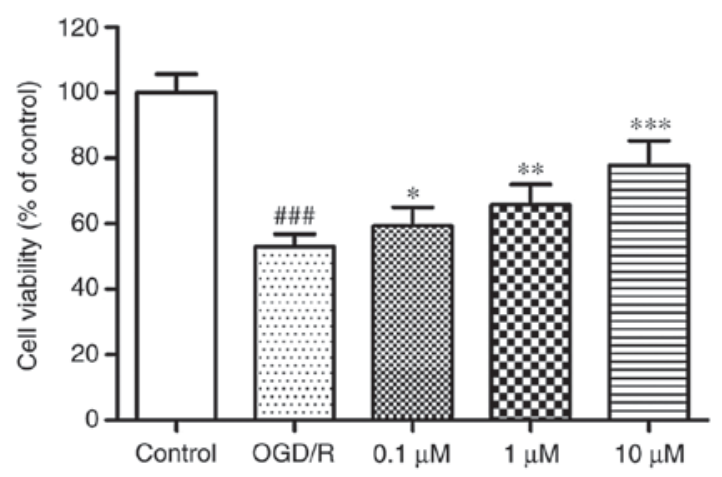

Figure 2. Effect of thevetiaflavone on cell viability in PC12 cells induced by $\mathrm{OGD} / \mathrm{R}$. Data are presented as the mean \pm standard deviation $(\mathrm{n}=6$,

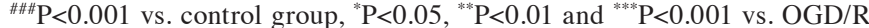
group). OGD/R, oxygen and glucose deprivation/reoxygenation.

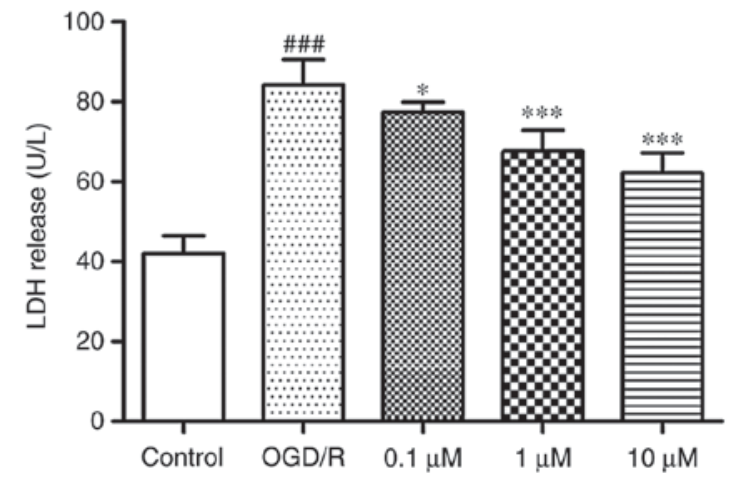

Figure 3. Effect of thevetiaflavone on the release LDH in PC12 cells induced by OGD/R. Data are presented as the mean \pm standard deviation $\left(\mathrm{n}=6,{ }^{\# \#} \mathrm{P}<0.001\right.$ vs. control group, ${ }^{*} \mathrm{P}<0.05$ and ${ }^{* * *} \mathrm{P}<0.001$ vs. OGD/R group). LDH, lactate dehydrogenase; OGD/R, oxygen and glucose deprivation/reoxygenation.

was observed $(58.16 \pm 6.74 \%, 63.42 \pm 8.26 \%$ and $81.40 \pm 4.45 \%$; Fig. 7). These results demonstrate the protective effects of thevetiaflavone on dysfunction of mitochondria in PC12 cells.

Effect of thevetiaflavone on ATP level in PC12 cells induced by $O G D / R$. The detection of intracellular ATP was further detected to confirm the protective effects of thevetiaflavone. As a result, thevetiaflavone can promote ATP production in a dosage-dependent manner $(63.54 \pm 6.83,71.89 \pm 7.33$ and $79.39 \pm 7.64 \%$ ), though OGD/R has induced the decline of ATP production $(53.93 \pm 6.30 \%, \mathrm{P}<0.001$ vs control group) in $\mathrm{PC} 12$ cells (Fig. 8).

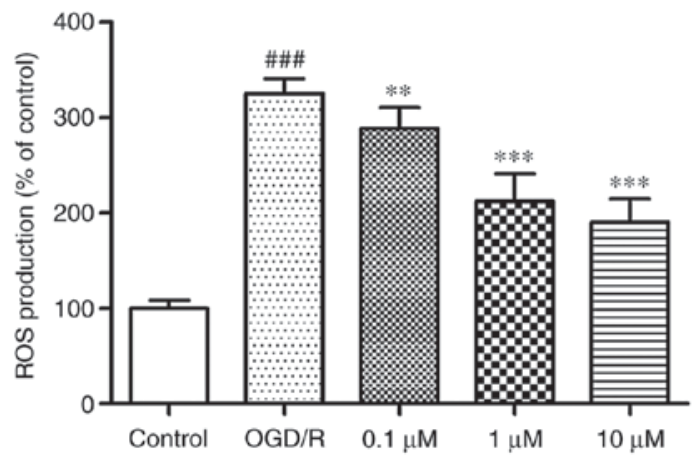

Figure 4. Effect of thevetiaflavone on ROS production in PC12 cells induced by OGD/R. Data are presented as the mean \pm standard deviation $\left(n=6,{ }^{\# \# \#} \mathrm{P}<0.001\right.$ vs. control group, ${ }^{* *} \mathrm{P}<0.01$ and ${ }^{* * * *} \mathrm{P}<0.001$ vs. OGD/R group). ROS, reactive oxygen species; OGD/R, oxygen and glucose deprivation/reoxygenation.

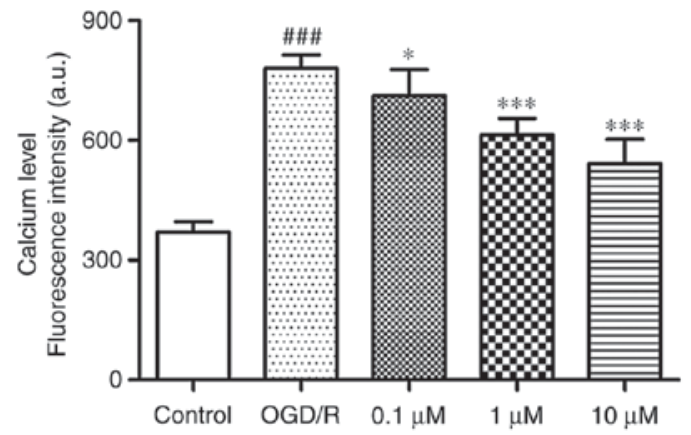

Figure 5. Effect of thevetiaflavone on intracellular calcium level in PC12 cells induced by $\mathrm{OGD} / \mathrm{R}$. Data are presented as the mean \pm standard deviation $\left(\mathrm{n}=6,{ }^{\# \# \#} \mathrm{P}<0.001\right.$ vs. control group, ${ }^{*} \mathrm{P}<0.05$ and ${ }^{* * * *} \mathrm{P}<0.001$ vs. $\mathrm{OGD} / \mathrm{R}$ group). OGD/R, oxygen and glucose deprivation/reoxygenation.

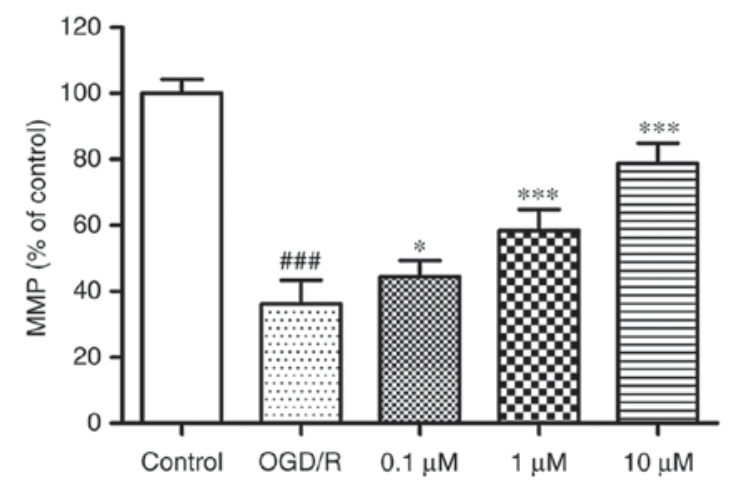

Figure 6. Effect of thevetiaflavone on MMP in PC12 cells induced by $\mathrm{OGD} / \mathrm{R}$. Data are presented as the mean \pm standard deviation $(\mathrm{n}=6$,

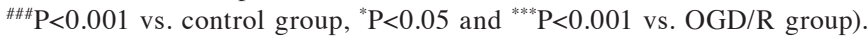
MMP, mitochondrial membrane potential; OGD/R, oxygen and glucose deprivation/reoxygenation.

Effect of thevetiaflavone on apoptosis of PC12 cells induced by $O G D / R$. To evaluate the protective effect of thevetiaflavone on PC12 cells induced by OGD/R against apoptosis, western blot analysis for caspase-3, Bcl-2 and Bax was implemented. In that analysis, following induction by $\mathrm{OGD} / \mathrm{R}$, the expression of Bcl-2 in PC12 cells was downregulated, whilst caspase-3 and Bax were upregulated. By contrast, with the pre-treatment of thevetiaflavone, the expression of $\mathrm{Bcl}-2$ was upregulated and 


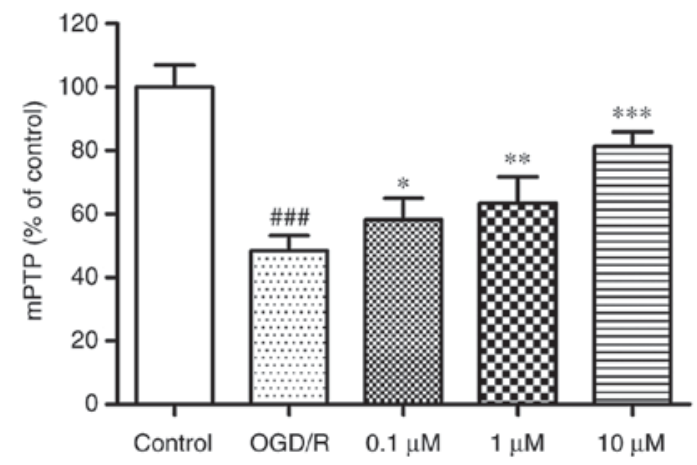

Figure 7. Effect of thevetiaflavone on mPTP in PC12 cells induced by $\mathrm{OGD} / \mathrm{R}$. Data are presented as the mean \pm standard deviation $(\mathrm{n}=6$,

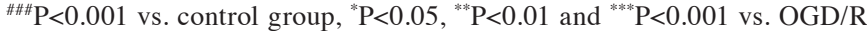
group). $\mathrm{mPTP}$, mitochondrial permeability transition pore; OGD/R, oxygen and glucose deprivation/reoxygenation.

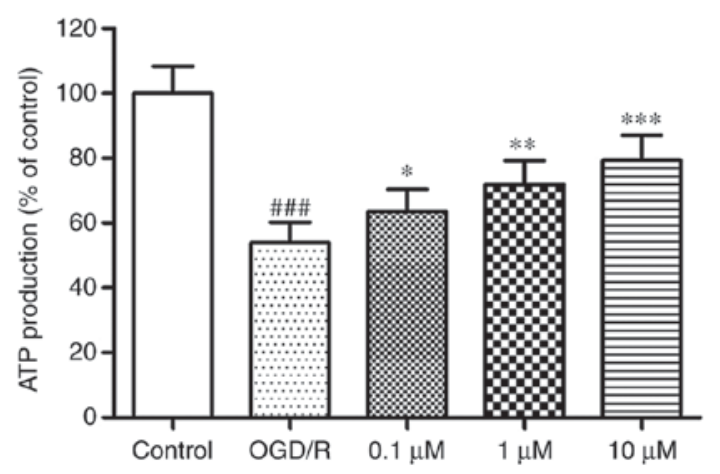

Figure 8. Effect of thevetiaflavone on ATP production in $\mathrm{PC} 12$ cells induced by OGD/R. Data are presented as the mean \pm standard deviation $(n=6$, ${ }^{\# \# \# P} \mathrm{P}<0.001$ vs. control group, ${ }^{*} \mathrm{P}<0.05,{ }^{* * *} \mathrm{P}<0.01$ and ${ }^{* * * *} \mathrm{P}<0.001$ vs. $\mathrm{OGD} / \mathrm{R}$ group). ATP, adenosine triphosphate; OGD/R, oxygen and glucose deprivation/reoxygenation.

caspase-3 together with Bax was downregulated (Fig. 9A) at the same time, the determination of caspase- 3 activity further indicated thevetiaflavone could attenuate PC12 cells apoptosis induced by $\mathrm{OGD} / \mathrm{R}(0.76 \pm 0.05,0.68 \pm 0.07$ and $0.57 \pm 0.06)$ by comparison with OGD/R group $(0.82 \pm 0.05)$ (Fig. $9 \mathrm{~B})$. These results elucidated the anti-apoptotic effects of thevetiaflavone on PC12 cells induced by OGD/R.

\section{Discussion}

Cerebral ischemia and reperfusion injury is caused by $\mathrm{OGD} / \mathrm{R}$ following the interruption of blood and results in infarction. Around the infarct area, the penumbral area can be attenuated through the inhibition of apoptosis (5). The activity of extracellular LDH is closely associated with cell viability, due to the fact that as a stable cytoplasmic enzyme in cells, LDH can be rapidly released into the culture medium when the plasma membrane is damaged (22). In our investigation, thevetiaflavone can attenuate the viability of PC12 cells injured by OGD/R. Further investigation on thevetiaflavone has indicated that it can reduce the increased extracellular LDH activity induced by OGD/R, which markedly confirmed the protective effects of thevetiaflavone on the injured PC12 cells.
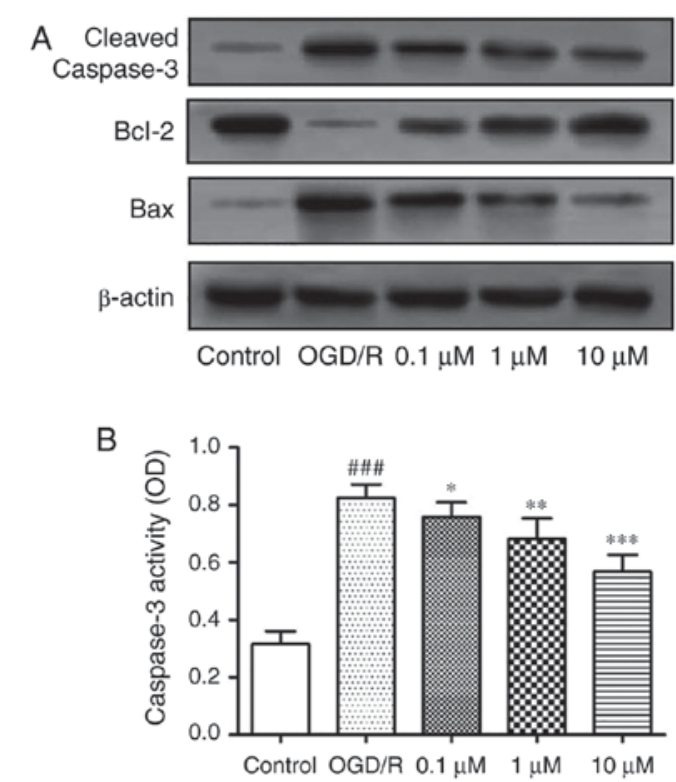

Figure 9. Effect of thevetiaflavone on cell apoptosis in PC12 cells induced by OGD/R. (A) Western blot analysis for proteins associated with apoptosis including caspase-3, Bcl-2 and Bax. (B) Caspase-3 activity affected by thevetiaflavone. Data are presented as the mean \pm standard deviation $(n=6$,

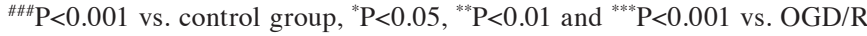
group). OGD/R, oxygen and glucose deprivation/reoxygenation; OD, optical density.

In cerebral ischemia and reperfusion, the neurons in the penumbra will undergo mitochondrion-mediated apoptosis without the improvement of ROS-induced mitochondrial dysfunction (5). Excessive ROS can interplay with $\mathrm{Ca}^{2+}$ and result in overload of $\mathrm{Ca}^{2+}$. The increasing intracellular $\mathrm{Ca}^{2+}$ will affect redox balance in turn to generate more $\operatorname{ROS}(20,23)$. As the major site of ROS production, mitochondria are both targets and sources of oxidative stress and susceptible to ROS (24). Oxidative stress is an activator of apoptosis through oxidative damage of the mitochondrial membrane proteins and lipids, which results in the dysfunction of mitochondria (25). In addition, the $\mathrm{Ca}^{2+}$ serves a central role in regulating mPTP opening through affecting ATP/ADP balance by tricarboxylic acid cycle, electron transport chain, and MMP (26). In the presence of thevetiaflavone, the mitochondrial dysfunction including overproduction of ROS, overload of $\mathrm{Ca}^{2+}$, collapse of MMP, mPTP opening and declined ATP was improved in PC12 cells induced by OGD/R, which demonstrated thevetiaflavone could ameliorate the mitochondrial dysfunction.

As a member of cysteine-dependent aspartate proteases family, caspase- 3 is one of the effector enzymes in apoptosis and activated through cleavage in ischemia (27). Bcl-2 and Bax are members of the $\mathrm{Bcl}-2$ protein family and involved in the mitochondrion-drove apoptosis through oligomerization (25). Bcl-2 displays anti-apoptotic effects and can attenuate the activation of caspase-3 while Bax exhibits pro-apoptotic effects (28). In PC12 cells, the expression of Bcl-2 was downregulated, whilst caspase- 3 and Bax was upregulated following the treatment of $\mathrm{OGD} / \mathrm{R}$, which indicated apoptosis occurred herein. In contrast, with thevetiaflavone, the expression of Bcl-2 was upregulated, whilst caspase- 3 and Bax were downregulated. The quantitative detection of caspase- 3 activity also obtained consistent results. These results indicate that 
thevetiaflavone can relieve the apoptosis induced by OGD/R in $\mathrm{PC} 12$ cells.

In summary, the current study has evaluated the protective effects of thevetiaflavone on PC12 cells injury induced by $\mathrm{OGD} / \mathrm{R}$. It is suggested that the mechanism is associated with the improvement of ROS-mediated mitochondrial dysfunction. These results provide a basis to further investigate the effects in vivo and suggests a potential application in clinical practice.

\section{Acknowledgements}

The current study was partly funded by Xuzhou Medical University (Xuzhou, China) (grant no. 2011KJZ07).

\section{References}

1. Feigin VL, Norrving B, George MG, Foltz JL, Roth GA and Mensah GA: Prevention of stroke: A strategic global imperative. Nat Rev Neurol 12: 501-512, 2016

2. Li JL, Wu L, Wu J, Feng HX, Wang HM, Fu Y, Zhang RJ, Zhang HY and Zhao WM: Caffeoyl triterpenoid esters as potential anti-ischemic stroke agents from Celastrus orbiculatus. J Nat Prod 79: 2774-2779, 2016.

3. Fisher M and Saver JL: Future directions of acute ischaemic stroke therapy. Lancet Neurol 14: 758-767, 2015.

4. Doyle KP, Simon RP and Stenzel-Poore MP: Mechanisms of ischemic brain damage. Neuropharmacology 55: 310-318, 2008.

5. Mehta SL, Manhas N and Raghubir R: Molecular targets in cerebral ischemia for developing novel therapeutics. Brain Res Rev 54: 34-66, 2007.

6. Thompson JW, Narayanan SV and Perez-Pinzon MA: Redox signaling pathways involved in neuronal ischemic preconditioning. Curr Neuropharmacol 10: 354-369, 2012.

7. Liu X, Zhu X, Chen M, Ge Q, Shen Y and Pan S: Resveratrol protects PC12 cells against OGD/R-induced apoptosis via the mitochondrial-mediated signaling pathway. Acta Biochim Biophys Sin (Shanghai) 48: 342-353, 2016.

8. Yang Z, Weian C, Susu H and Hanmin W: Protective effects of mangiferin on cerebral ischemia-reperfusion injury and its mechanisms. Eur J Pharmacol 771: 145-151, 2016.

9. Wang S, Xu H, Xin Y, Li M, Fu W, Wang Y, Lu Z, Yu X and Sui D: Neuroprotective effects of kaempferide-7-O-(4'-O-acet ylrhamnosyl)-3-O-rutinoside on cerebral ischemia-reperfusion injury in rats. Eur J Pharmacol 788: 335-342, 2016.

10. Ho WS, Xue JY, Sun SS, Ooi VE and Li YL: Antiviral activity of daphnoretin isolated from Wikstroemia indica. Phytother Res 24: 657-661, 2010.

11. Nunome S, Ishiyama A, Kobayashi M, Otogulo K, Kiyohara H, Yamada $\mathrm{H}$ and Omura S: In vitro antimalarial activity of biflavonoids from Wikstroemia indica. Planta Med 70: 76-78, 2004
12. Hu K, Kobayashi H, Dong A, Iwasaki S and Yao X: Antifungal, antimitotic and anti-HIV-1 agents from the roots of Wikstroemia indica. Planta Med 66: 564-567, 2000.

13. Zhang X, Wang G, Huang W, Ye W and Li Y: Biflavonoids from the roots of Wikstroemia indica. Nat Prod Commun 6: 1111-1114, 2011.

14. Wang GC, Zhang XL, Wang YF, Li GQ, Ye WC and Li YL: Four new dilignans from the roots of Wikstroemia indica. Chem Pharm Bull (Tokyo) 60: 920-923, 2012.

15. Wang LY, Unehara N and Kitanaka S: Lignans from the roots of Wikstroemia indica and their DPPH radical scavenging and nitric oxide inhibitory activities. Chem Pharm Bull (Tokyo) 53: 1348-1351, 2005

16. Chen Y, Fu WW, Sun LX, Wang Q, Qi W and Yu H: A new coumarin from Wikstroemia indica (L.) C. A. Mey. Chin Chem Lett 20: 592-594, 2009.

17. Lu CL, Li YM, Fu GQ, Yang LI, Jiang JG, Zhu L, Lin FL, Chen J and Lin QS: Extraction optimisation of daphnoretin from root bark of Wikstroemia indica (L.) C.A. and its anti-tumour activity tests. Food Chem 124: 1500-1506, 2011

18. Me H, Zhong $\mathrm{Y}$ and Yin J: Chemical constituents from Wikstroemia indica. Chin Trad Herbal Drugs 38: 669-670, 2007 (In Chinese).

19. Cai M, Ma Y, Zhang W, Wang S, Wang Y, Tian L, Peng Z, Wang $\mathrm{H}$ and Qingrong T: Apigenin-7-O- $\beta$-D-(-6'-p-coumaroyl) -glucopyranoside treatment elicits neuroprotective effect against experimental ischemic stroke. Int J Biol Sci 12: 42-52, 2016.

20. Agrawal M, Kumar V, Singh AK, Kashyap MP, Khanna VK, Siddiqui MA and Pant AB: Trans-resveratrol protects ischemic PC12 cells by inhibiting the hypoxia associated transcription factors and increasing the levels of antioxidant defense enzymes. ACS Chem Neurosci 4: 285-294, 2013.

21. Li YY, Xiao L, Qiu LY, Yan YF, Wang H, Duan GL, Liao ZP and Chen HP: Sasanquasaponin-induced cardioprotection involves inhibition of mPTP opening via attenuating intracellular chloride accumulation. Fitoterapia 116: 1-9, 2017.

22. Zhu JR, Tao YF, Lou S and Wu ZM: Protective effects of ginsenoside $\mathrm{Rb}(3)$ on oxygen and glucose deprivation-induced ischemic injury in PC12 cells. Acta Pharmacol Sin 31: 273-280, 2010.

23. Görlach A, Bertram K, Hudecova S and Krizanova O: Calcium and ROS: A mutual interplay. Redox Biol 6: 260-271, 2015.

24. Fiskum G, Rosenthal RE, Vereczki V, Martin E, Hoffman GE, Chinopoulos $\mathrm{C}$ and Kowaltowski A: Protection against ischemic brain injury by inhibition of mitochondrial oxidative stress. J Bioenerg Biomembr 36: 347-352, 2004.

25. Niizuma K, Endo H and Chan PH: Oxidative stress and mitochondrial dysfunction as determinants of ischemic neuronal death and survival. J Neurochem 109 Suppl 1: 133-138, 2009.

26. Hurst S, Hoek J and Sheu SS: Mitochondrial Ca2+ and regulation of the permeability transition pore. J Bioenerg Biomembr 49 : 27-47, 2017

27. Chan PH: Reactive oxygen radicals in signaling and damage in the ischemic brain. J Cereb Blood Flow Metab 21: 2-14, 2001

28. Youle RJ and Strasser A: The BCL-2 protein family: Opposing activities that mediate cell death. Nat Rev Mol Cell Biol 9: 47-59, 2008. 